\title{
MOTOR DEVELOPMENT OF CHILDREN WITH VISUAL IMPAIRMENT
}

\author{
Ivana Sretenović ${ }^{1}$ \\ Goran Nedović
}

Original scientific paper

University of Belgrade, Faculty of Special Education and Rehabilitation, Belgrade, Serbia

Received: $2018 / 12 / 11$

Accepted: 2019/2/14

\begin{abstract}
The aim of this study was to determine the level of motor development of children with visual impairment and comparison with peers of typical development. The research sample consisted of a total of 135 children with visual impairment and children with typical development, 7-10 years old, of both sexes. The Bruininks-Oseretsky Test of Motor Proficiency, $2^{\text {nd }}$ edition was used to estimate motor development. The methods of descriptive statistics, as well as the T-test of independent samples, and the Hi square test were used in statistical processing of the obtained data. The results of the study had shown that the level of motor development of the subjects with visual impairment was below and well below the average for their age. Typical development subjects are mostly within the average norms.
\end{abstract}

Keywords: BOT-2, motor development, students with visual impairments, vision

\section{INTRODUCTION}

Motor development can be defined as a gradual change in the motor behavior of each person, which is the result of the interaction between the personal characteristics, the environment in which the person is and the types of motor tasks that are being performed (Gallahue, 2002).

The deficit in any domain of child development affects the development of the remaining domains (Bigelow, 2003), so numerous findings indicate that children with visual impairments have a delay in motor development (Brambring, 2001; Houwen, Visscher, Lemmink, \& Hartman, 2008; Howarth et al., 2003; Levtzion-Korach, Tennenbaum, Schnitzer \& Ornoy, 2000; Wyver \& Livesey, 2003).
The vision is one of the most important senses, as well as a complete or partial loss leads to very serious consequences in the development and life of a person (Angelopoulou-Sakantami, 2002, according to Fotiadou, Chtistodoulou, Soulis, Tsimaras, \& Mousouli, 2014). Children with visual impairments are faced with difficulties in the domains of cognitive, social and motor development, and even very little visual impairment may disturb the domain of motor development, because the sense of sight closely related to motor skills, specifically with motor activity, programming and execution of movement (Brambring, 2006; Navarro, Fukuyama, Fontes, Matas \& Prado, 2004, according to Daly, Malone, Burkett, Gabrys \& Satkunskiene, 2009).

\footnotetext{
${ }^{1}$ Correspondence to:

Ivana Sretenović, Faculty of Special Education and Rehabilitation, University of Belgrade, Belgrade, Serbia Belgrade, Serbia

E-mail: ivana.sretenovic011@gmail.com
} 
When we say that the vision closely related to motor skills or motor abilities, this can be explained by the fact that a child observes their hands and fingers in such a way that he begins to examine and run them. This is the beginning of visuomotor control, which later plays an important role in the development of (psycho) motor skills (Bojanin, 1985). Visual impairments have a negative impact on general motor activity and can lead to developmental delays. The effect of visual damage is different for each stage of development (Reimer, Cox, Nijhuis-Van der Sanden, \& Boonstra, 2011). As visual impairments have a negative impact on motor development, the negative impact is also manifested in the development of motor abilities and later on the acquisition of motor skills (Atasavun \& Dulge, 2011; Bouchard \& Tetreault 2000; Brambring, 2006, 2007; Reimer, SmitsEngelsman, \& Siemonsma-Boom, 1999; Rutkowska et al., 2016; Zylka, Lach, \& Rutkowska, 2013, all according to Sretenović \& Nedović, 2018).

Numerous studies have identified deficits in motor development in children with visual impairments compared with their peers with typical development (Atasavum, Usal, \& Aki, 2012; Fotiadou et al., 2014; Wyver \& Livesey, 2003).

The aim of the research was to determine the level of motor development in children with visual impairment and whether there was a difference in the motor development of children with visual impairment and children of typical development.

\section{METHODS}

\section{The sample}

The research was carried out in accordance with the Helsinki Declaration on Ethical Principles for Medical Research Involving Human Subjects. The study was approved by the Professional Boards of the University of Belgrade (No. 61206-186 / 2-15). Taking into account that the subjects of the research were children, a written consent was received from the parents or the guardian. The survey sample included 135 children, aged 7 to 15 , both sexes. The sample is divided into two groups. The first group of examinees consisted of 45 (33.3\%) children with visual impairment, the average age 10.67 $(\mathrm{SD}=3.337)$ years, both sexes $(35.6 \%$ of boys) were uniform compared to the full structure $(\chi 2=3.756, \mathrm{df}=$ $1, \mathrm{p}=.053)$. The second group of respondents consisted of $90(66.67 \%)$ children of typical development, the average age was $10.67(\mathrm{SD}=3.318)$, both sexes $(50 \%$ of boys).

\section{Place and time of research}

The research was carried out during the school year 2016/2017., in schools for the education of children with disabilities and regular primary schools located in the territory of the Republic of Serbia.

\section{Research instrument}

The Bruininks-Oseretsky Test of Motor Proficiency, Second Edition - BOT-2 (Bruininks \& Bruininks, 2005) was used to evaluate motor development. This test has been widely used to evaluate motor development, or a wide range of motor skills in children aged 4 to 21 . It consists of 8 subtests (fine motor precision, fine motor integration, manual dexterity, bilateral coordination, balance, running speed and agility, upper limb coordination and strength). By combining these subtests, four motor areas are obtained which by combining give the total motor composite score.

\section{Statistical data processing}

In the part of the preliminary analysis, the normality of the distribution of the obtained results was calculated using the Kolmogorov-Smirnov test, which further focused on the selection of parametric techniques because the normality, distribution and homogeneity of the variance were respected. For the descriptive statistics of categorical variables, the counting measures were used: the frequency $(\mathrm{N})$ and the percentage $(\%)$, while for the descriptive statistics of numerical variables the measures of central tendency were used: arithmetic mean (M) and variation measures: standard deviation (SD) and standard error of average (SEM). Also, the T test for independent samples was used. The $\chi 2$ test was used to analyze two categorical variables. All statistical analyzes had been assigned an $\alpha$ level of .05. The statistical package of SPSS for social sciences was used for data processing. 


\section{RESULTS}

Table 1. The Average Achievement of Subjects with Visual Impairment and Subjects of Typical Development on BOT-2

\begin{tabular}{|c|c|c|c|c|c|c|c|c|}
\hline \multirow{3}{*}{ BOT-2 } & \multicolumn{8}{|c|}{ Subjects } \\
\hline & \multicolumn{4}{|c|}{ Visual impairment } & \multicolumn{4}{|c|}{ Typical development } \\
\hline & $\mathbf{M}$ & SD & Min & Max & $\mathbf{M}$ & SD & Min & Max \\
\hline Subtest 1 & 4.02 & 2.911 & 1 & 13 & 7.31 & 1.647 & 3 & 12 \\
\hline Subtest 2 & 5.91 & 3.795 & 1 & 16 & 8.82 & 2.424 & 5 & 16 \\
\hline Subtest 3 & 3.84 & 2.449 & 1 & 9 & 11.27 & 3.576 & 5 & 23 \\
\hline Subtest 4 & 5.29 & 3.245 & 1 & 12 & 15.62 & 3.968 & 7 & 24 \\
\hline Subtest 5 & 5.36 & 3.206 & 1 & 18 & 13.12 & 4.019 & 7 & 24 \\
\hline Subtest 6 & 5.11 & 3.304 & 1 & 12 & 16.97 & 3.501 & 8 & 27 \\
\hline Subtest 7 & 5.09 & 3.872 & 1 & 16 & 12.49 & 4.404 & 5 & 23 \\
\hline Subtest 8 & 5.47 & 3.428 & 1 & 15 & 15.10 & 3.419 & 8 & 23 \\
\hline Total motor composite score & 25.73 & 5.280 & 20 & 40 & 41.19 & 5.542 & 32 & 58 \\
\hline
\end{tabular}

Average achievements on the subtests show that those with visual impairment achieved the worst achievement on subtest 3 (manual dexterity) and achieved the best average achievement on subtest 2 (fine motor integration). At the same time, in the group of subjects of typical development, the best average achievement was on subtest 6 (running speed and agility), while the worst result was obtained on subtest 1 (fine motor precision). If we compare the total motor composite scores of these two groups of subjects, we can see that subjects of typical development $(\mathrm{M}=41.19, \mathrm{SD}$ $=5.542$ ) are significantly better than those with visual impairment $(\mathrm{M}=25.73, \mathrm{SD}=5.280)($ Table 1$)$. The T-test of independent samples found that there was statistically significant difference between these two groups of subjects $(\mathrm{t}(133)=15.51, \mathrm{p}=.000)$. The mean difference between the groups (mean difference $=15.46,95 \%$ CI: $13.48-17.43)$ was large $(\eta 2=$ .644 ), and the type of development explains as much as $64.4 \%$ of the variance of motor development

Table 2. Descriptive Display of Achievement

\begin{tabular}{|c|c|c|c|c|c|}
\hline \multirow[t]{3}{*}{ Descriptive categories } & \multicolumn{4}{|c|}{ Subjects } & \multirow{3}{*}{ Total } \\
\hline & \multicolumn{2}{|c|}{ Visual impairment } & \multicolumn{2}{|c|}{ Typical development } & \\
\hline & Male & Female & Male & Female & \\
\hline Average & l & / & $22(16.3 \%)$ & $22(16.3 \%)$ & $44(32.59 \%)$ \\
\hline Below average & $3(2.22 \%)$ & $4(2.96 \%)$ & $23(17.04 \%)$ & $23(17.04 \%)$ & $53(39.26 \%)$ \\
\hline Well below average & $13(9.62 \%)$ & $25(18.52 \%)$ & l & l & $38(28.15 \%)$ \\
\hline Total & $16(11.85 \%)$ & $29(21.48 \%)$ & $45(33.33 \%)$ & $45(33.33 \%)$ & $135(100.00 \%)$ \\
\hline
\end{tabular}

Based on the results given in Table 2, and according to the descriptive categories of motor development, we can say that compared to the total sample, only $44(32.59 \%)$ of the subjects, and that typical develop- ment subjects, are in the average for their age, while $39.26 \%$ of subjects are below average, and $28.15 \%$ well below the average. 
Table 3. Average Achievement of Subjects with Visual Impairment and Subjects of Typical Development in Relation to Gender on the Total Motor Composite Score

\section{Subjects}

Visual Impairment

Typical development

\begin{tabular}{|c|c|c|c|c|c|c|c|c|c|c|c|}
\hline \multicolumn{3}{|c|}{ Male } & \multicolumn{3}{|c|}{ Female } & \multicolumn{3}{|c|}{ Male } & \multicolumn{3}{|c|}{ Female } \\
\hline $\mathrm{M}$ & SD & $\mathrm{SE}_{\mathrm{M}}$ & $\mathrm{M}$ & SD & $\mathrm{SE}_{\mathrm{M}}$ & $\mathrm{M}$ & SD & $\mathrm{SE}_{\mathrm{M}}$ & $\mathrm{M}$ & SD & $\mathrm{SE}_{\mathrm{M}}$ \\
\hline 26.75 & 6.137 & 1.534 & 25.17 & 4.766 & .885 & 41.53 & 5.806 & .866 & 40.84 & 5.308 & .791 \\
\hline
\end{tabular}

T-test for independent samples were compared to the results obtained on the total motor composite score of subjects with visual impairment of both sexes as well as the subjects with typical development of both sexes. There was no significant difference in the results of boys $(\mathrm{M}=26.7, \mathrm{SD}=6.137)$, and girls $(\mathrm{M}=25.1, \mathrm{SD}$ $=4.766$ ) with visual impairment, $\mathrm{t}(43)=.958, \mathrm{p}=.343$. The difference between the median meanings by groups (mean difference $=1.578,95 \%$ CI: -1.742 to 4.897 ) was small $(\mathrm{\eta} 2=.021)$. The sexual difference explains only $2.1 \%$ of the variance of motor development. In the group of subjects with typical development, also there was no significant difference in achievement in boys $(\mathrm{M}=41.5$, $\mathrm{SD}=5.806)$, and girls $(\mathrm{M}=40.8, \mathrm{SD}=5.308), \mathrm{t}(88)$ $=.587, \mathrm{p}=.558$. The difference between the median meanings by groups (mean difference $=.689,95 \% \mathrm{CI}$ : -1.642 to 3.019$)$ was small ( $\eta 2=.003)$, and sex explains only .3\% of the variance of motor development.

\section{DISCUSSION}

With this research we wanted to examine the level of motor development in children with visual impairment, and to compare the motor development of children with visual impairment to children of typical development. Children with visual impairment, in relation to the descriptive categories of motor development, are in the category below the average and well below the average in relation to their age. It is very worrying that about $40 \%$ subjects of typical development are in the category below average. This result can be explain to today's way of life of children. There is a growing presence of sedentary lifestyles (Pate, Mitchell, Byun, \& Dowda, 2011), an irregular diet that leads to either overweight or malnutrition (Bremer \& Cairney, 2018), then spending spare time on a computer, tablet, or mobile phone, not in a park or playground. Our findings are partially confirmed by the findings of other studies, which stated that those with visual impairment belong to the category below average and respondents of the typical devel- opment category above average (Fotiadou et al., 2014). It is evident that respondents with visual impairment have significantly lower achievements $(\mathrm{M}=25.73$, SD $=5.280)$ than their peers of typical development $(\mathrm{M}=$ $41.19, \mathrm{SD}=5.542$ ), which is somewhat expected, and numerous studies suggest that the vision is the dominant sense in humans (Bouchard \& Tetreault, 2000; Levtzion-Korach et al., 2000, all according to Haegele, Brian, \& Goodway, 2015; Hashemi, Dehghani, Saboonch, Roozbahani, \& Roonasi, 2012), and have a very important role in acquiring motor skills, ie children with visual impairment have less developed motility than children of typical development (Aslan, Calik, \& Kitis, 2012; Houwen, Hartman \& Visscher, 2009; Kozub \& Oh, 2004; Lieberman \& McHugh, 2001). Delays in acquiring motor can be one of the factors that contribute to the differences between these two groups of children (Houwen, Visscher, Hartman, \& Lemmink, 2007; Houwen, Hartman, Jonker, \& Visscher, 2010). The expectation and justification of the results that the subjects with visual impairment have significantly lower achievements than the subjects of typical development, are also reflected in the fact that the type of development explains as much as $64.4 \%$ of variance in motor development, according to the results of this study. If we observe the achievements on the subtests, we can say that for those with visual impairment the best developed is a fine motor integration, and the worst manual dexterity. The data in the literature state that the subjects with visual impairment had the greatest delay in dribbling and catching the ball (Houwen et al., 2010; Wagner, Haibach, \& Lieberman, 2013), which is not in accordance with our findings. Between boys and girls with visual impairment, as well as boys and girls of typical development, no statistically significant difference was found on the total motor composite score, and sex explains the extremely low percentage of variance in motor development. In other words, gender has no significant role in the development of motor abilities, respectively motor development. 
Confirmation of our results found in other studies $(\mathrm{Ca}-$ meto \& Nagle, 2007; Pereira, 1990). However, there are also studies whose findings confirm the existence of a difference in the motor development of boys and girls with visual impairment, in favor of male children (Fotiadou et al., 2014).

\section{CONCLUSION}

Based on the results of the study, we can say that subjects with visual impairment are late in motor development compared to their peers of typical development. Subjects with visual impairments are below average and well below average for their age. Motor development depends on the presence or absence of disabilities, while on the other hand, the gender does not greatly affect motor development. In line with these results, we believe that programs for motor development should be structured primarily in relation to skills, namely to be profiled in relation to the type of disorder. As a limitation of the study, we present a relatively small sample of children with visual impairment, but also children of typical development. Some of the next surveys should include a larger sample, another age category, and grouping children with visual impairment in relation to the level of visual impairment.

\section{REFERENCES}

Aslan, U. B., Calik, B. B., \& Kitis, A. (2012). The Effect of Gender and Level of Vision on the Physical Activity Level of Children and Adolescents with Visual Impairment. Research in Developmental Disabilities, 33(6), 799-804.

Atasavun, U. S., \& Düger, T. (2012). Visual perception training on social skills and activity performance in low-vision children. Scandinavian Journal of Occupational Therapy, 19(1), 33-41.

Bigelow, A. (2003). The Development of Joint Attention in Blind Infants. Development and Psychopathology, 15, 259-75.

Bojanin, S. (1985). Neuropsihologija razvojnog doba i opšti reedukativni metod. Beograd: Zavod za udžbenike i nastavna sredstva.

Brambring, M. (2006). Divergent development of gross motor skills in children who are blind or sighted. Journal of Visual Impairment \& Blindness, 100(10), 620-634.

Brambring, M. (2001). Motor activity in children who are blind or partially sighted. Visual Impairment Research, 3, 4151.

Bremer, E., \& Cairney, J. (2018). Fundamental Movement Skills and Health-Related Outcomes: A Narrative Review of Longitudinal and Intervention Studies Targeting Typically Developing Children. American Journal of Lifestyle Medicine, 12(2), 148-159, https://doi. org/10.1177/1559827616640196.
Bruininks, R., \& Bruininks, B. (2005). Bruininks-Oseretsky Test of Motor Proficiency, second edition (BOT-2). Minneapolis, MN: Pearson Assessment.

Cameto, R., \& Nagle, K. (2007). Facts from NLTS2: Orientation and mobility skills of secondary school students with visual impairments. Menlo Park, CA: SRI International.

Daly, D., Malone, L.A., Burkett, B., Gabrys, T., \& Satkunskiene, D. (2009). Is sight the main deterrent to race performance in visually impaired competitive swimmers. FACTA UNIVERSITATIS, Series: Physical Education and Sport, 7 (1), $1-15$.

Fotiadou, E., Christodoulou, P., Soulis, S-G., Tsimaras, V.K., \& Mousoul, M. (2014). Motor Development and SelfEsteem of Children and Adolescents with Visual Impairment. Journal of Education and Practice, 5 (37), 97-106.

Gallahue, D. L. (2002). Classifying movement skills: A case for multidimensional models. Revista da Educacao Fiscal UEM, 13(2), 105-111.

Haegele, J., Brian, A., \& Goodway, J. (2015). Fundamental Motor Skills and School-Aged Individuals with Visual Impairments: a Review. Review Journal of Autism and Developmental Disorders, 2 (3), 320-327, https://doi. org/10.1007/s40489-015-0055-8.

Hashemi, M., Dehghani, D., Saboonch, R., Roozbahani, M., \& Roonasi, A. (2012). Effect of Gymnastic Skills on Motor Capabilities of 7-10 Age Group Girls with Visually Impaired. European Journal of Experimental Biology, 2(3), 786-791.

Houwen, S., Hartman, E., Jonker, L., \& Visscher, C. (2010). Reliability and validity of the TGMD-2 in primary schoolaged children with visual impairments. Adapted Physical Activity Quarterly, 27(2), 149-159.

Houwen, S., Hartman, E., \& Visscher, C. (2009). Physical activity and motor skills in children with and without visual impairments. Medicine and Science in Sport and Exercise, 41, 103-109.

Houwen, S., Visscher, C., Lemmink, K.A., \& Hartman, E. (2008). Motor skill performance of school-age children with visual impairments. Developmental Medicine and Child Neurology, 50, 139-145.

Houwen, S., Visscher, C., Hartman, E., \& Lemmink, K. (2007). Gross motor skills and sport participation of children with visual impairment. Research Quarterly for Exercise and Sport, 78(1), 16-23.

Hovart, M., Ray, C., Ramsey, V. K., Miszko, T., Keeney, R., \& Blasch, B. B. (2003). Compensatory analysis and strategies for balance in individuals with visual impairments. Journal of Visual Impairment \& Blindness, 97, 695-703.

Kozub, F., \& Oh, H. (2004). An exploratory study of physical activity levels in children and adolescents with visual impairments. Clinical Kinesiology, 58 (3), 1-7.

Levtzion-Korach, O., Tennenbaum, A. Schnitzer, R., \& Ornoy, A. (2000). Early motor development of blind children. Journal of Paediatrics and Child Health, 36, 226-229.

Lieberman, L. J., \& McHugh, B. E. (2001). Health-related fitness of children with visual impairments and blindness. Journal of Visual Impairment and Blindness, 95(5), 272-286.

Pate, R. R., Mitchell, J. A., Byun, W., \& Dowda, M. (2011). Sedentary behaviour in youth. British Journal of Sports Medicine, 45, 906-913. doi:10.1136/bjsports-2011-090192. 
Pereira, L. M. (1990). Spatial concepts and balance performance: Motor learning in blind and visually impaired children. Journal of Visual Impairment \& Blindness, 84, 109-111.

Reimer, A., Cox, R., Nijhuis-van der Sanden, R., \& Boonstra, N. (2011). Improvement of fine motor skills in children with visual impairment: An explorative study. Research in Developmental Disabilities, 32 (5), 1924-1933.

Sretenović, I., \& Nedović, G. (2018). Razlike u motoričkim sposobnostima djece s oštećenjem vida u dobi od 7,10 i 15 godina. U S. Šalaj (Ur.), Zbornik radova 4. znanstvenostručne konferencije „Motorička znanja djece“, 31.08.2018. Zagreb; Organizator: Kineziološki fakultet Sveučilišta u Zagrebu (str. 256-261). Zagreb: Kineziološki fakultet Sveučilišta u Zagrebu. ISBN: 978-953-317-061-9.
Wagner, M., Haibach, P., \& Lieberman, L. (2013). Gross motor skill performance in children with and without visual impairments - research to practice. Research in Developmental Disabilities, 34(10), 3246-3252. doi: 10.1016/j. ridd.2013.06.030.

Wyver, S., \& Livesey, D. (2003). Kinaesthetic sensitivity and motor skills of school-aged children with a congenital visual impairment. British Journal of Visual Impairment, 21(1), $25-31$. 